\title{
24. SEISMIC STRATIGRAPHIC SECTIONS: EAST MARIANA BASIN (SITE 585), NAURU BASIN (SITE 462), AND ONTONG-JAVA PLATEAU (SITE 586) ${ }^{1}$
}

\author{
Jill M. Whitman, Geologic Research Division, Scripps Institution of Oceanography²
}

\begin{abstract}
The newly installed digital seismic system on the Glomar Challenger was used to collect data in the Mariana Basin (Site 585), in the Nauru Basin (Site 462), and on the Ontong-Java Plateau (Site 586). The drilling results from Sites 585 and 462 correlate with the seismic data of the basins, allowing multidimensional interpretation of their histories since the middle of the Cretaceous. On the Ontong-Java Plateau, the data suggest the activity of erosional processes.
\end{abstract}

\section{INTRODUCTION}

Leg 89 was the first cruise of the Glomar Challenger to collect digital seismic data. The computer system and related seismic interfaces were installed on the ship while it was in dry dock in Yokohama, Japan, immediately before the cruise. First tests of any new system can result in failure and frustration, or in success; the tests of this system on Leg 89 yielded all of these. Ultimately, nearly $64 \mathrm{hrs}$. of data were successfully collected, adding to the existing coverage of the western Pacific. This chapter presents some of the seismic data collected during Leg 89.

\section{SEISMIC SYSTEM}

A Hewlett-Packard 1000 Series E computer was installed on the Glomar Challenger with a seismic interface card designed by the Marine Technology Group at Scripps Institution of Oceanography. Both air guns and a water gun were used as sound sources for this system. Single-channel digital seismic data were recorded in real time on magnetic tapes, using SEG-Y format. In this format, all the data from a single seismic shot are recorded as a single physical record, preceded by additional information in the trace header. The sample rate was $1 \mathrm{kHz}$. An antialias filter of $1 \mathrm{~ms}$ was used, and the shot interval was $10 \mathrm{~s}$. Although variable during the cruise, the speed of the ship was generally 9-10 knots while underway between sites. The software for data acquisition is compatible with the system used on Scripps Institution of Oceanography ships, thus making possible shore-based processing at the S10 campus.

\section{DATA COLLECTED}

Leg 89 began in Yokohama, Japan on 11 October 1982. Three sites $(585,462$, and 586$)$ were drilled, in the Mariana Basin, in the Nauru Basin, and on the OntongJava Plateau, respectively (Fig. 1). The final port was Noumea, New Caledonia, reached on 29 November.

After initial start-up problems had been solved, recording began during the approach to the first site, Site 585, in the Mariana Basin. During the second portion of the cruise, data were recorded nearly continuously between Site 585 and Site 462 in the Nauru Basin. Various difficulties arose with the seismic interface, and only one additional section of data could be recorded, on

\footnotetext{
${ }^{1}$ Moberly, R., Schlanger, S. O., et al., Init. Repts. DSDP, 89: Washington (U.S. Govt. Printing Office)

2 Address: Geologic Research Division, A-008, Scripps Institution of Oceanography, University of California, San Diego, La Jolla, CA 92093.
}

the Ontong-Java Plateau southeast of Site 586. Figure 1 and Table 1 indicate the portions of the cruise where data were recorded.

The data were processed on the Scripps PRIME computer, using SIOSEIS, a processing and plotting program written by Paul Henkart (copyright 1981). Various balances of filtering, automatic gain control (AGC), and deconvolution were applied to each of the sections of data to optimize the display. In addition, effort was made to show the range of options available with SIOSEIS.

\section{Mariana Basin}

A north-south seismic profile through the Mariana Basin was collected during the approach to and departure from Site 585 (Fig. 2 and 3). Two air guns (60 and $120 \mathrm{in.}^{3}$ ) were used in this basin, at water depths of about $6100 \mathrm{~m}$.

These data complement an east-west profile collected in the Mariana Basin in the fall of 1981 by the Kana Keoki (Shipley et al., 1983; Petersen et al., this volume), which used two 80 -in. ${ }^{3}$ water guns as the sound source (Fig. 4). Together, these two profiles afford a three-dimensional view of the basin.

Drilling at Site 585 recovered a $900-\mathrm{m}$ section composed almost entirely of reworked and redeposited material (Site 585 Chapter, this volume; see summary in Fig. 4). In the airgun seismic sections, reflectors in the interval between 8.10 and $8.74 \mathrm{~s}$ are laterally continuous and can be traced across the entire basin to onlap the seamounts to the north and south (Figs. 2 and 3 ). This portion of the section is correlated with the fine-grained pelagic turbidites (lithologic Units I-V), which become finer-grained upward in the stratigraphic section at this site. Distinct reflectors at 8.4 and $8.6 \mathrm{~s}$ are interpreted as the chert horizons recovered in lithologic Units II and IV.

The top of the volcaniclastic sediments at $590 \mathrm{~m}$ subbottom (the boundary between Units V and VI) is correlated with a continuous, high-amplitude reflector at $8.74 \mathrm{~s}$. This reflector can also be traced to onlap the volcanic highs around the basin. Below the reflector, the sedimentary section is composed of coarse-grained proximal turbidites derived from the constructional phases of the seamounts. The major change in lithology occurs at the transition between acoustic Units V3 and V4, and 


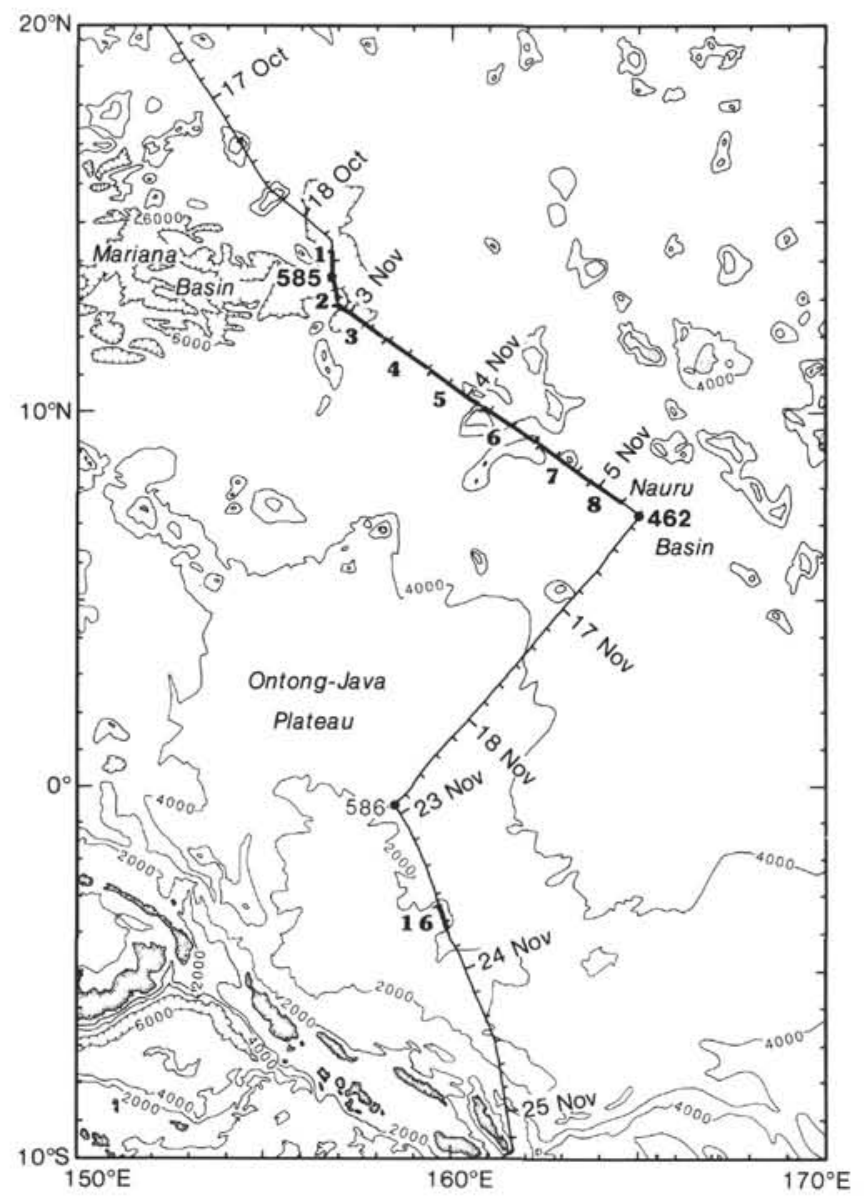

Figure 1. Bathymetry of the western Pacific (after Iwabuchi, 1979) (2000-m contour interval) showing cruise track of Leg 89, with tick marks at 4-hr. intervals; 0000 GMT each day is indicated by the date. Locations of DSDP sites drilled during the cruise are indicated by large dots and numbers. Thickened sections of the cruise track represent the portions of leg where seismic data were digitally collected. Bold numbers along these thickened portions correspond to the tape number of the data (see Table 1 for further details).

is marked by an increase in acoustic velocity (see Physical Properties section, Site 585 Chapter, this volume).

The prominent reflector at $8.96 \mathrm{~s}$ is correlated with the marked increase in cementation of the volcaniclastic material at $800 \mathrm{~m}$. This transition is also distinguished by a sharp increase in velocity, between acoustic Units V4 and V5, from 2.2 to $3.2 \mathrm{~km} / \mathrm{s}$, determined on the basis of shipboard measurements of physical properties (Site 585 Chapter, this volume). The total penetration was to $9.2 \mathrm{~s}$. The seismic stratigraphy and history of this basin are discussed in greater detail by Whitman et al. (this volume).

\section{Ita Maitai Guyot}

After leaving Site 585, the Glomar Challenger crossed the top of Ita Maitai Guyot. The flat summit of the guyot in water depths of about $1450 \mathrm{~m}$, is shown in Figure 5. Penetration was limited $(0.3 \mathrm{~s})$, but two different sequences of reflections are distinguishable. The upper $0.1 \mathrm{~s}$ is characterized by moderate-amplitude, high-continuity, parallel reflections. This sequence probably represents pelagic sedimentation on top of the guyot. The
Table 1. Digital seismic data collected during Leg 89.

\begin{tabular}{|c|c|c|c|}
\hline Tape no. & Date/time (GMT) & Sound source & Tape coverage \\
\hline 1 & $\begin{array}{c}18 \text { October } 1982 \\
0652-1125 Z\end{array}$ & $\begin{array}{l}\text { Two air guns } \\
(120 \text { and } \\
\left.60 \text { in. }{ }^{3}\right)\end{array}$ & $\begin{array}{l}\text { Mariana Basin, } \\
\text { from flanks of } \\
\text { seamount to } \\
\text { Site } 585\end{array}$ \\
\hline 2 & $\begin{array}{c}2 \text { November } 1982 \\
1802-2032 Z\end{array}$ & $\begin{array}{l}\text { Two air guns } \\
(120 \text { and } \\
\left.60 \text { in. }{ }^{3}\right)\end{array}$ & $\begin{array}{l}\text { Mariana Basin, } \\
\text { leaving Site } 585 \\
\text { and flanks of } \\
\text { Ita Maitai }\end{array}$ \\
\hline 3 & $\begin{array}{l}\text { 2-3 November } 1982 \\
2056-0708 \mathrm{Z}\end{array}$ & $\begin{array}{l}\text { Two air guns } \\
(120 \text { and } \\
\left.60 \text { in. }{ }^{3}\right)\end{array}$ & $\begin{array}{l}\text { From top of Ita } \\
\text { Maitai into } \\
\text { southern arm of } \\
\text { Mariana Basin }\end{array}$ \\
\hline 4 & $\begin{array}{c}3 \text { November } 1982 \\
0728-1557 Z\end{array}$ & $\begin{array}{l}\text { Two air guns } \\
\qquad \begin{array}{l}(120 \text { and } \\
\left.60 \text { in. }^{3}\right)\end{array}\end{array}$ & Marshall Seamounts \\
\hline 5 & $\begin{array}{c}\text { 3-4 November } 1982 \\
1711-0233 Z\end{array}$ & $\begin{array}{l}\text { Two air guns } \\
\qquad \begin{array}{l}(120 \text { and } \\
\left.60 \text { in. }^{3}\right)\end{array}\end{array}$ & Marshall Seamounts \\
\hline 6 & $\begin{array}{c}4 \text { November } 1982 \\
0242-1223 Z\end{array}$ & $\begin{array}{l}\text { Two air guns } \\
(120 \text { and } \\
\left.60 \text { in. }^{3}\right)\end{array}$ & Marshall Seamounts \\
\hline 7 & $\begin{array}{c}4 \text { November } 1982 \\
1232-2154 Z\end{array}$ & $\begin{array}{l}\text { Two air guns } \\
\qquad \begin{array}{l}(120 \text { and } \\
\left.60 \text { in. }^{3}\right)\end{array}\end{array}$ & $\begin{array}{l}\text { Marshall Seamounts } \\
\text { into Nauru } \\
\text { Basin }\end{array}$ \\
\hline 8 & $\begin{array}{l}\text { 4-5 November } 1982 \\
2210-0401 Z\end{array}$ & $\begin{array}{l}\text { Two air guns } \\
\text { (120 and } \\
\left.60 \text { in. }^{3}\right)\end{array}$ & $\begin{array}{l}\text { Nauru Basin to Site } \\
462\end{array}$ \\
\hline 16 & $\begin{array}{c}23 \text { November } 1982 \\
1403-1705 Z\end{array}$ & $\begin{array}{l}\text { Water gun } \\
\left(80 \text { in. }^{3}\right)\end{array}$ & $\begin{array}{c}\text { Ontong-Java } \\
\text { Plateau }\end{array}$ \\
\hline
\end{tabular}

lower sequence of high-amplitude and moderate-continuity reflections, showing significant relief, may be associated with a phase of erosion that Ita Maitai experienced while near sea level during Late Cretaceous (Heezen, MacGregor, et al., 1973).

A profile off the flank of Ita Maitai into the basin to the southeast is shown in Figure 6. On bathymetric maps of the Mariana Basin (Iwabuchi, 1979; Mammerickx and Smith, 1985), an arm of the deepest part of the basin ( $>6000 \mathrm{~m},>8.0 \mathrm{~s}$ ) extends southward around the east side of Ita Maitai. The profile shown in Figure 6 crosses this portion of the basin (Fig. 1). The stratigraphy in this profile is similar to that in Figures 2 and 3, and presumably would be similar to that drilled at Site 585 . The reflectors in Figure 6 onlap the flanks of the seamount, and they appear to represent a basin-filling sequence of presumed turbidite origin. Penetration was only $0.7 \mathrm{~s}$, less than that shown in Figures 2 and 3.

The data collected between the Mariana Basin and the Nauru Basin are not reproduced in this chapter. They form a traverse across the southwestern region of the Marshall Seamounts, and show small basins with thin sediments and limited penetration $(0.3 \mathrm{~s})$ between many steeply flanked seamounts.

\section{Nauru Basin}

Seismic reflection data were collected in the Nauru Basin during the northwest approach to Site 462 (Fig. 7). The water depth in this basin is approximately $5140 \mathrm{~m}$; use of two air guns (120 and 60 in. $\left.{ }^{3}\right)$ resulted in an acoustic penetration of $0.8 \mathrm{~s}$.

Drilling at this site began during Leg 61 (Holes 462 and $462 \mathrm{~A}$ ) and was continued in Hole $462 \mathrm{~A}$ on Leg 89. Total penetration at this site was $1209 \mathrm{~m}$. Correlation of the seismic data with the drilling results at this site is 


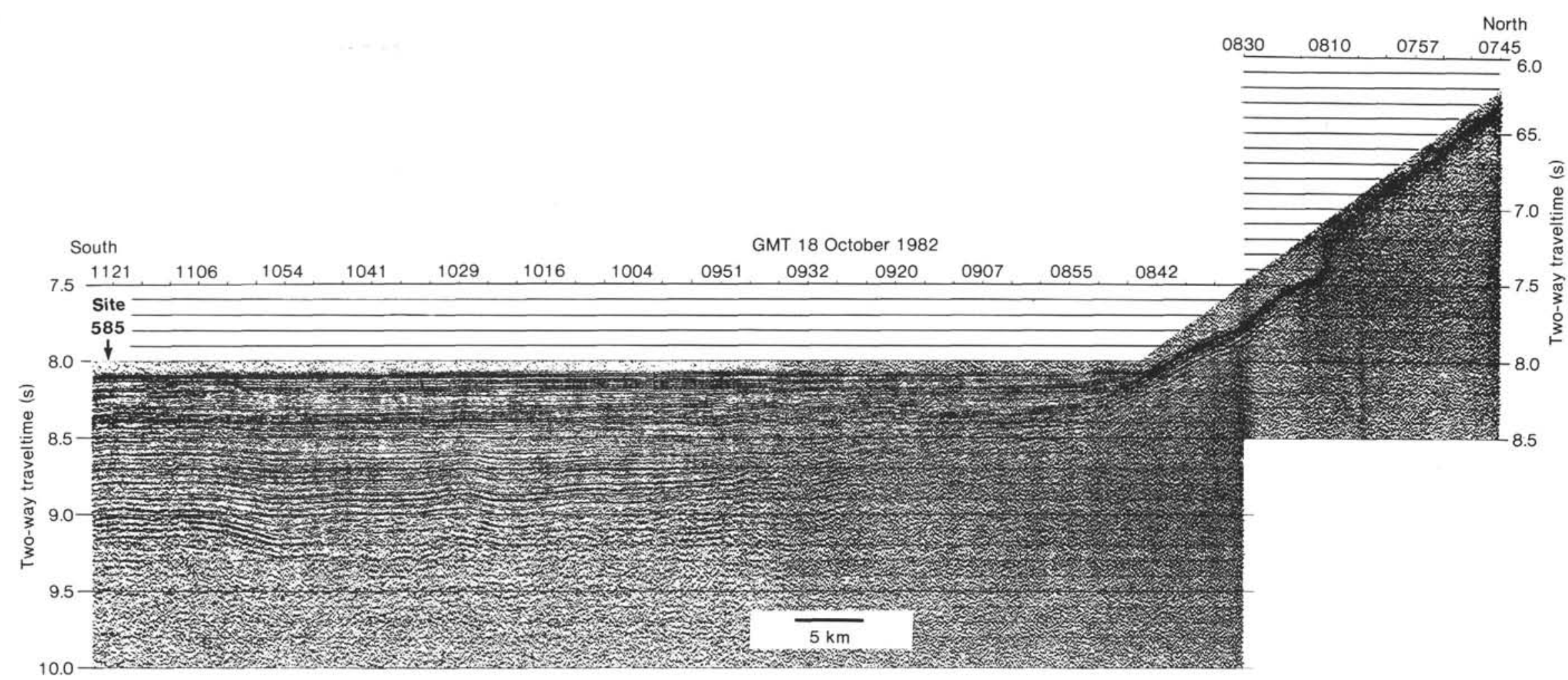

Figure 2. Seismic reflection profile collected during approach to Site 585 in the Mariana Basin (Tape 1), from 0745 to 1125 GMT on 18 October 1982 , using two air guns (120 and 60 in. ${ }^{3}$ ). Data processed with bandpass filter $(15-100 \mathrm{~Hz}), 0.5$-s AGC window, and deconvolved (1-s interval, 0.160 -s filter length, and $100 \%$ prewhitener). 


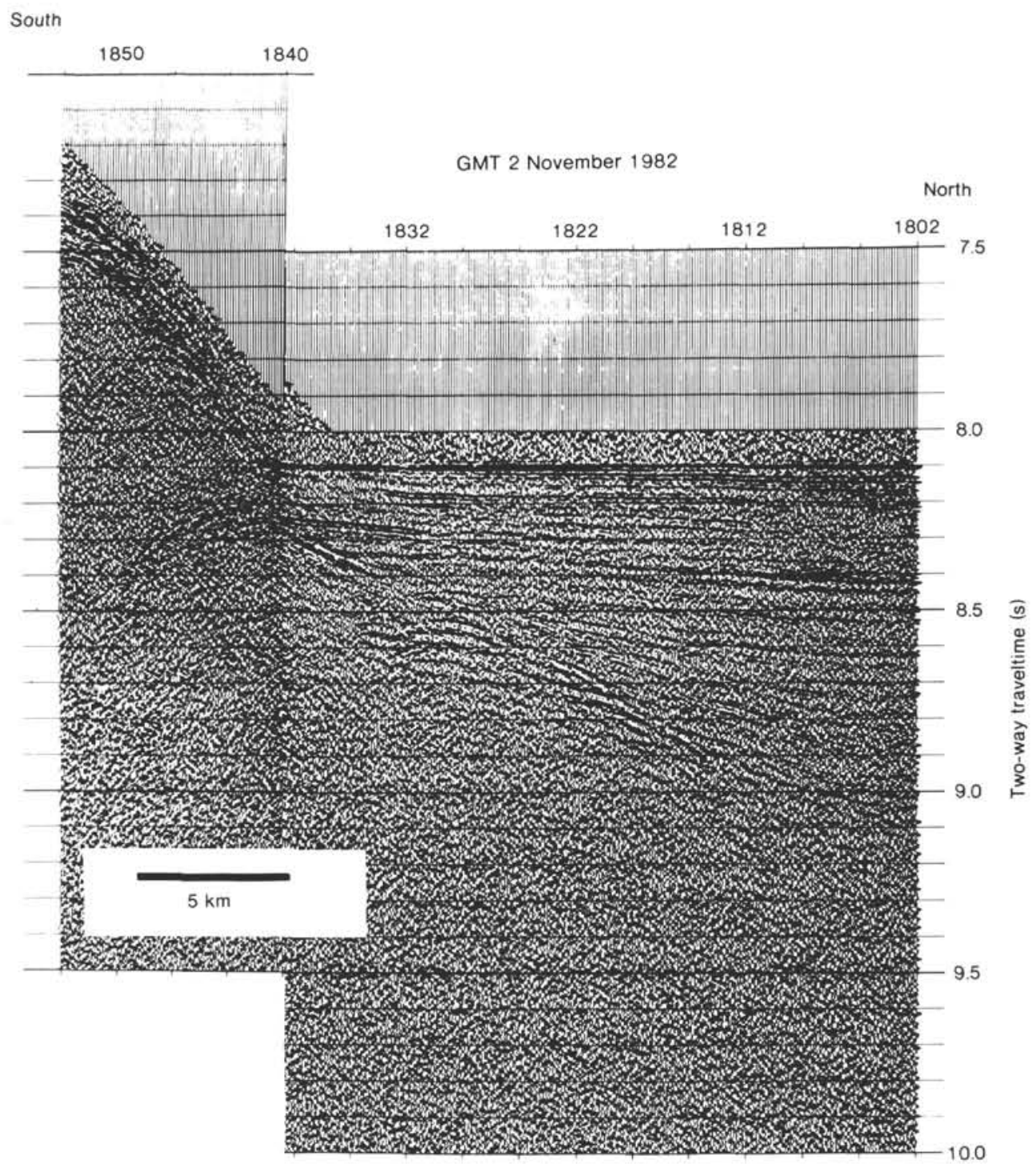

Figure 3. Seismic reflection profile collected during departure from Site 585 in the Mariana Basin (Tape 2), from 1802 to 1853 GMT on 2 November 1982, using two air guns (120 and 60 in. $\left.{ }^{3}\right)$. Data processed as in Figure 2.

shown in Figure 7. The high-continuity, moderate-amplitude, parallel reflectors in the upper $0.5 \mathrm{~s}$ of the section (Fig. 7A) represent the Paleocene to Recent chalks and oozes drilled in the upper $450 \mathrm{~m}$ at the site. The closely spaced, moderate-continuity, high-amplitude reflections between 7.35 and $7.40 \mathrm{~s}$ are correlated with the volcanogenic sediments overlying the basalt sills and flows encountered at $560 \mathrm{~m}$. A single high- to moderate-continuity, high-amplitude reflection at $7.45 \mathrm{~s}$ has reverberations (Fig. 7B) which were removed by deconvolution (Fig. 7A). This reflector is correlated with the top of the basalt complex, and may represent the reverberant layer found throughout the western Pacific (Houtz and Ludwig, 1979).

\section{Ontong-Java Plateau}

Problems with the seismic data acquisition system prevented digital recording between Site 462 in the Nauru Basin and Site 586 on the Ontong-Java Plateau. One fi- nal section of data (Fig. 8) was collected southeast of Site 586, across a shallow portion of the Ontong-Java Plateau (water depth about $2000 \mathrm{~m}$ ). The sound source for this section was one 80 -in. ${ }^{3}$ water gun, and acoustic penetration was at least $1.0 \mathrm{~s}$. Moderate-amplitude, highcontinuity parallel reflections are present throughout the upper $0.8 \mathrm{~s}$ of the section. High-amplitude, high-continuity reflections at $0.8 \mathrm{~s}$ sub-bottom show moderate relief, and the underlying moderate-amplitude, moderatecontinuity reflections at $1.0 \mathrm{~s}$ sub-bottom (acoustic basement?) show significant relief. The variations in surface topography of the section do not always mirror the underlying topography; this suggests erosional channels on the modern seafloor (e.g., 1520 and 1545-1555 GMT).

\section{CONCLUSIONS}

High-quality seismic reflection data were collected during Leg 89 in a variety of sedimentary environments in the western Pacific Ocean. Processing has enhanced the 


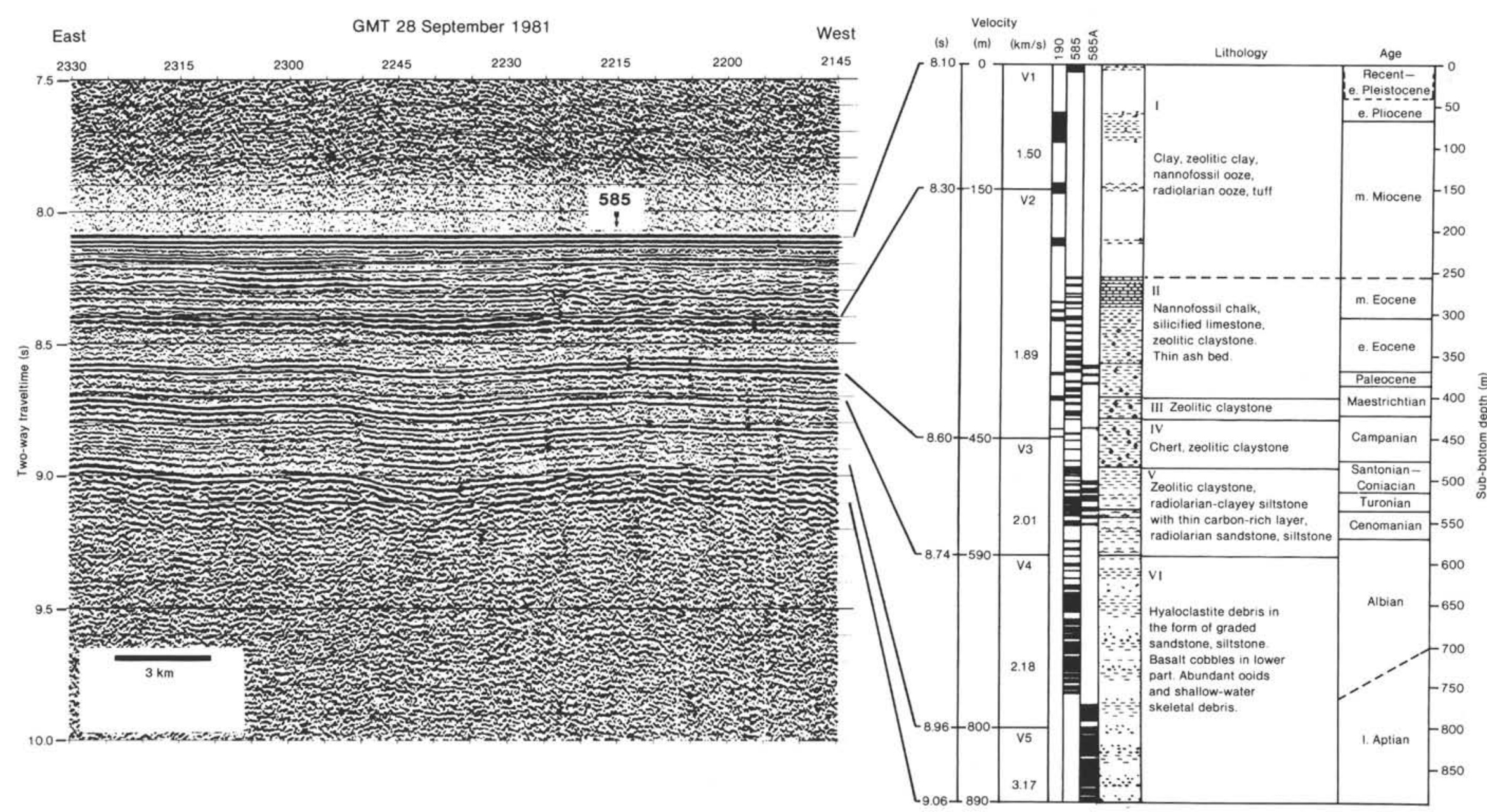

Figure 4. Correlation of drilling results at Sites 199 and 585 with seismic reflection section (collected by the Kana Keoki) in the Mariana Basin near Site 585 (from Whitman et al., this volume). Section was recorded using two 80 -in. ${ }^{3}$ water guns; bandpass filter $(25-120 \mathrm{~Hz}$ ), and 0.5 -s AGC window were applied. Acoustic units (V1-V5) at Site 585 and lithologic units (I-VI) based on drilling results at Site 585 are labeled. The depths of the seismic reflectors listed in the stratigraphic column (in seconds) are the depths at which the reflectors occur at Site 585 . The tie lines between the stratigraphic column and the seismic section are drawn to the reflectors at the depths where they occur at the edge of the seismic section. 


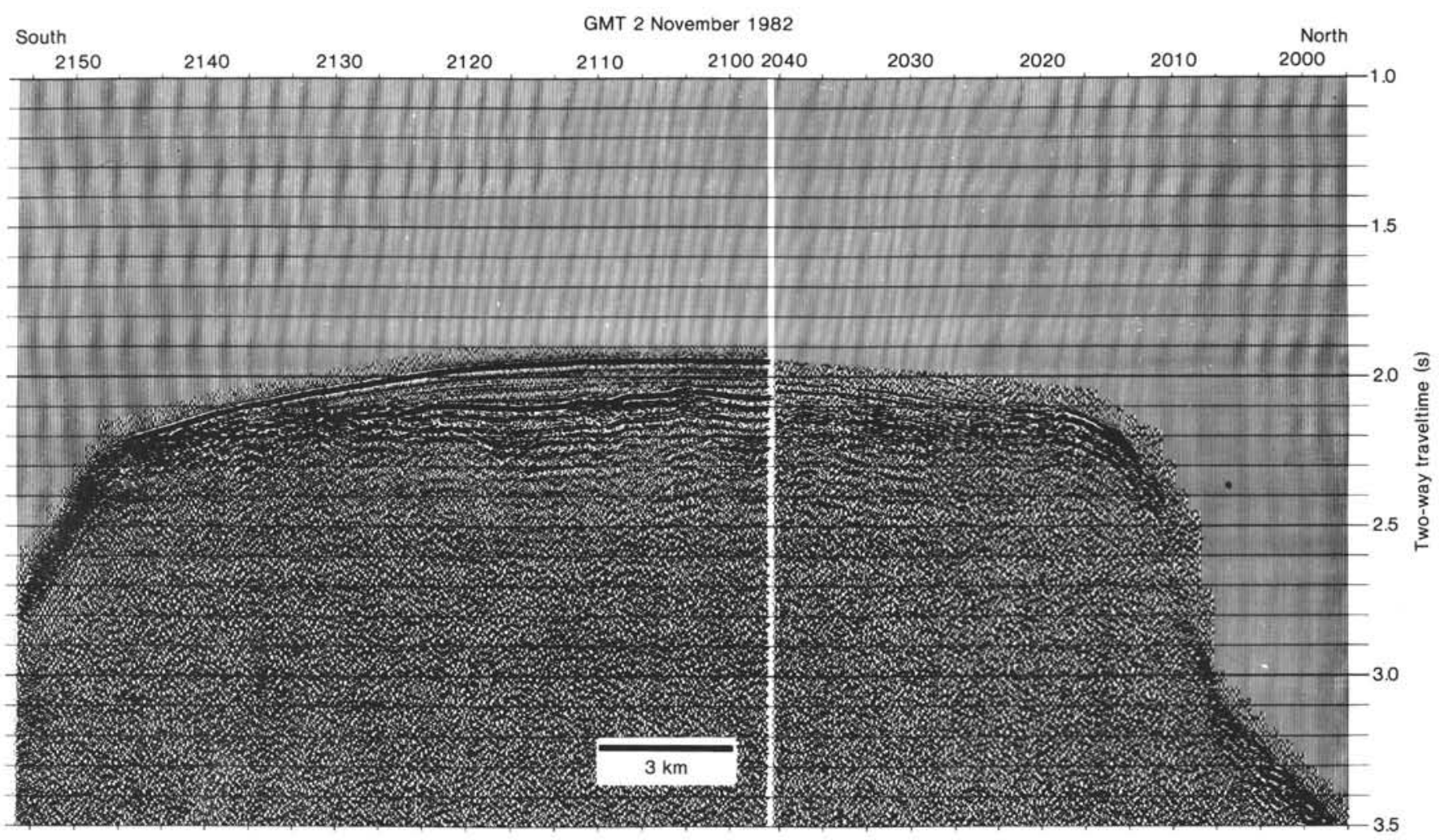

Figure 5. Seismic reflection profile across Ita Maitai Guyot (combined from Tapes 2 and 3). The section was recorded from 1956 to 2154 GMT on 2 November 1982, using two air guns $\left(120\right.$ and 60 in. $\left.{ }^{3}\right)$. The data were processed with a bandpass filter $(10-100 \mathrm{~Hz})$ and 0.5 -s AGC window. The gap in the section is due to the change of recording tapes, and resulted in the loss of about $15 \mathrm{~min}$. of data. Problems with the data recording system produced poorer-quality data in the first portion (1956-2040 GMT); the problem was rectified before the second tape started.

South

GMT 2-3 November 1982

\begin{tabular}{|c|c|c|c|c|c|c|c|c|c|}
\hline South & & & & 2-3 No & 982 & & & & North \\
\hline 0110 & 0100 & 0050 & 0040 & 0030 & 0020 & 0010 & 0000 & 2350 & 2340 \\
\hline
\end{tabular}

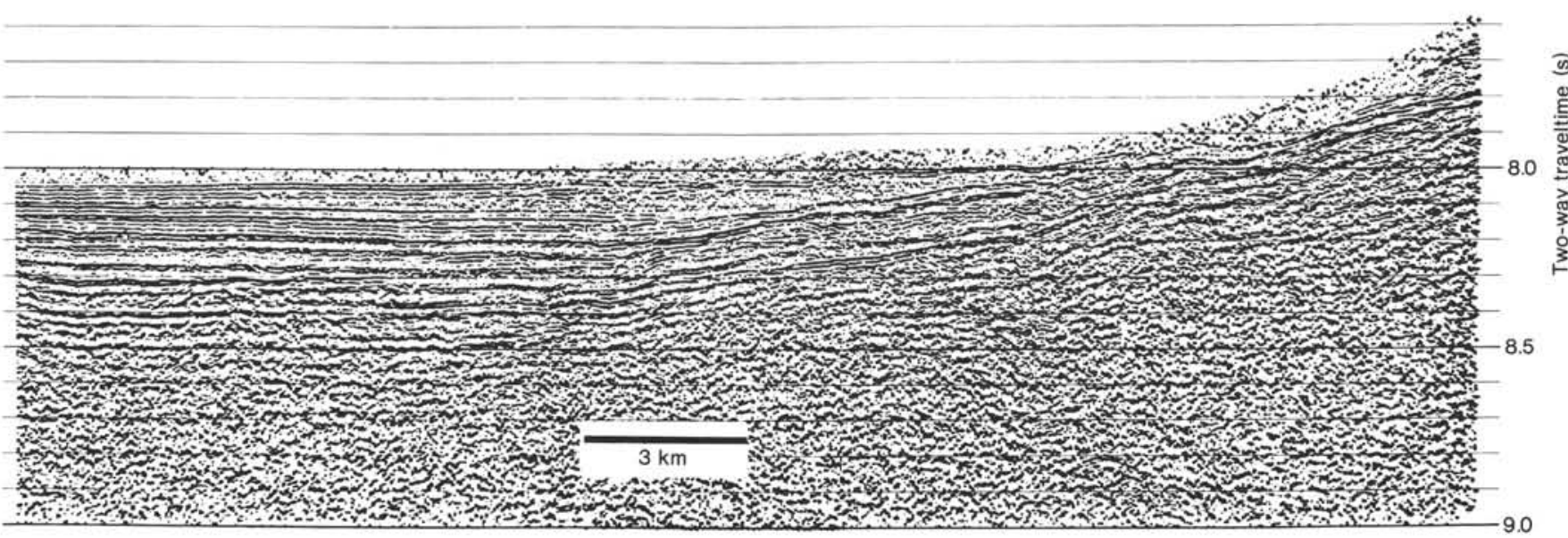

Figure 6. Seismic reflection profile of Mariana Basin to the southeast of Ita Maitai Guyot (Tape 3). This section was recorded from 2340 GMT on 2 November to 0057 GMT on 3 November 1982, with two air guns $\left(120\right.$ and 60 in. $\left.{ }^{3}\right)$. The data were processed with a bandpass filter $(10-100 \mathrm{~Hz})$ and 0.2-s AGC window. 


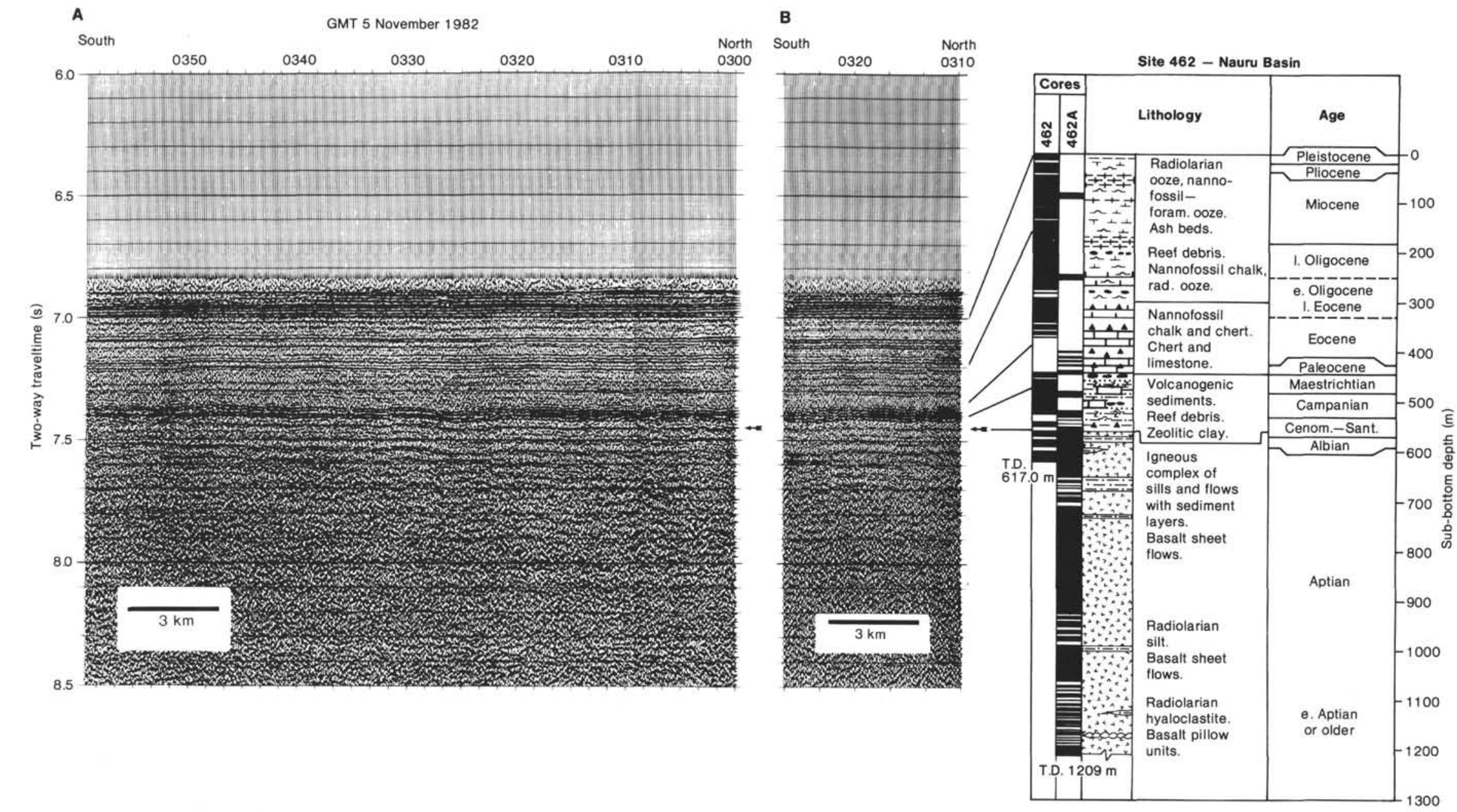

B

Figure 7. Correlation of drilling results (after Moberly et al., 1983) with seismic reflection profile near Site 462 in the Nauru Basin. The data were collected from 0300 to 0359 GMT on 5 November 1982 (Tape 8), using two air guns (120 and $60 \mathrm{in}^{3}$ ); they were processed with bandpass filter (10-100 Hz) and 0.5 -s AGC window. A. Deconvolved (1-s interval, 0.160 -s filter length, and $25 \%$ prewhitener) data. Note the strong reflector at $7.45 \mathrm{~s}$, which is correlated with the top of the volcanics drilled at the site (arrow). B. Same section in Nauru Basin (0310-0326 GMT), processed as in Figure 7A, but without deconvolution. Note reflector at $7.45 \mathrm{~s}$, which has reverberant characteristics. 


\section{J. M. WHITMAN}

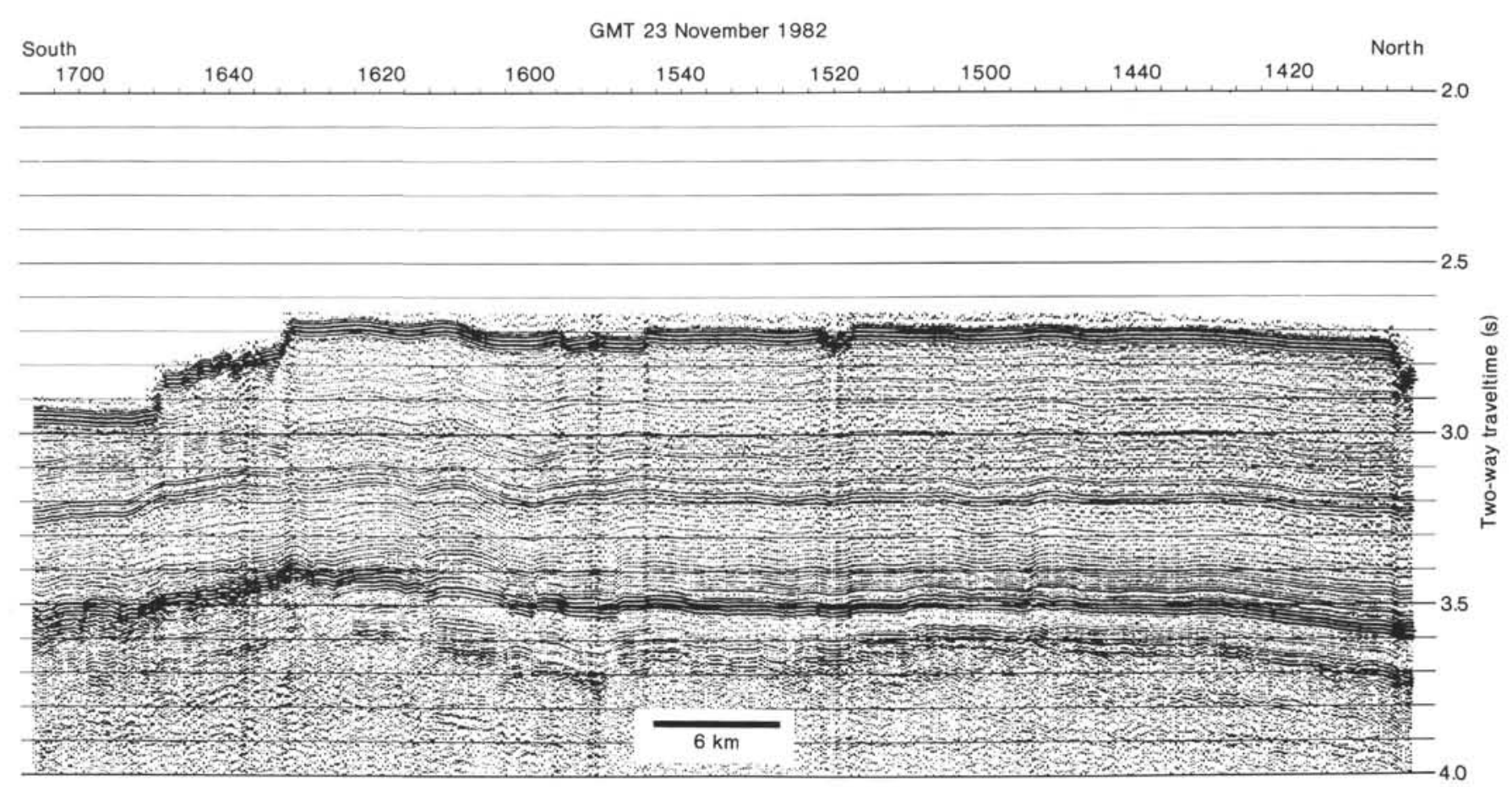

Figure 8. Seismic reflection profile from the Ontong-Java Plateau, southeast of Site 586 (Tape 16), from 1403 to 1705 GMT on 23 November 1982 , using one 80 -in. ${ }^{3}$ water gun. The data were processed with bandpass filter $(25-125 \mathrm{~Hz})$ and 0.5 -s AGC window. Every other trace of the data is plotted to reduce the horizontal scale.

data, and allows correlation with drilling results at Sites 585 in the Mariana Basin and Site 462 in the Nauru Basin.

\section{ACKNOWLEDGMENTS}

I want to thank Tom Shipley, who first introduced me to the study of seismic reflection data and with whom the precruise study of the Mariana Basin was completed. Thanks also to Paul Henkart, who created and maintains the seismic processing system at Scripps and provides constant consulting to those processing data. Peter Woodbury was instrumental in setting up the new seismic system on the Glomar Challenger, and provided the information about the operation of the system. The systems operators on board the Challenger during Leg 89 deserve credit for overcoming great obstacles to collect data successfully during the first operation of the system. Thanks to G. S. Mountain, who reviewed the manuscript. This work was supported by grants JOI 41-81, IPOD/NSF-C-482, and USN N00014-80-C-0440, and by the Whole Earth Society.

\section{REFERENCES}

Heezen, B. C., MacGregor, I. D., et al., 1973. Oolitic limestone on the Ita Maitai Guyot, equatorial Pacific: DSDP Site 202. In Hee- zen, B. C., MacGregor, I. D., et al., Init. Repts. DSDP, 20: Washington (U.S. Govt. Printing Office), 97-102.

Houtz, R. E., and Ludwig, W. J., 1979. Distribution of reverberant subbottom layer in the southwest Pacific basin. J. Geophys. Res., 84:3497-3504.

Iwabuchi, Y., 1979. General Bathymetric Chart of the Oceans: Ottawa, Canada (Canadian Hydrographic Office), sheet 5.06.

Mammerickx, J., and Smith, S. M., 1985. Bathymetry of the North central Pacific. Geol. Soc. Am., Map and Chart Series MC-52.

Moberly, R., Schlanger, S. O., Baltuck, M., Bergen, J. A., Dean, W., et al., 1983. Leg 89 drills Cretaceous volcanics. Geotimes, 28:17-20.

Shipley, T. H., Whitman, J. M., Duennebier, F. K., and Petersen, L. D., 1983. Seismic stratigraphy and sedimentation history of the East Mariana Basin, western Pacific. Earth Planet Sci. Lett., 64: 257-275.

Date of Initial Receipt: 11 February 1985

Date of Acceptance: 11 April 1985 